\title{
Trade Liberalization and Productivity Growth: A Firm-level Analysis from Kenya
}

\author{
STEPHEN ESAKU* \\ Department of Business and Management at Cavendish University \\ Uganda, Kampala, Uganda.
}

WALDO KRUGELL

School of Economic Sciences, North-West University

Potchefstroom, South Africa

\begin{abstract}
In this paper, we analyze the impact of trade liberalization on firm productivity growth in Kenya's manufacturing sector. Using a long panel spanning 8 years; 1992-1999, we conduct our analysis in a regression framework. Our analysis reveals that liberalizing trade generates high productivity improvements in the manufacturing sector. We find that a oneunit reduction in import duties as a percentage of total imports significantly increases firmlevel productivity in the manufacturing sector by $5.7 \%$. When we examine this effect on the firm's share of exported output, we find that lowering of import duties significantly increases the share of output exported by $0.7 \%$. Further, we sought to assess how the effect of import duties varies across the different industries in our sample. Examining the effect of import duties on industrial performance, we find a negative and statistically significant relationship in some of the industries. Our results show heterogeneous effect of reduction in import duties on industrial performance. Not all industries benefited from the lowering of import duties, especially the food and bakery, and garment industry, where productivity did not increase. These findings have important policy implications for improving the manufacturing sector. Consequently, formulating policies that effectively relax restrictive barriers to trade in the economy could speed up firm-level productivity in the manufacturing sector.
\end{abstract}

Keywords: Firm-Level; Productivity growth; Trade; Trade Liberalization

JEL Classifications: D20, D24, F14, O24

\footnotetext{
*Esaku: Corresponding Author. Email: esaku_stephen@yahoo.com / sesaku@cavendish.ac.ug; Krugell: waldo.krugell@nwu.ac.za

(C) 2020 Stephen Esaku and Waldo Krugell. Licensed under the Creative Commons Attribution Noncommercial 4.0 Licence (http://creativecommons.org/licenses/by-nc/4.0/. Available at http: //rofea.org.
} 


\section{Introduction}

Does trade liberalization generate firm-level productivity growth? This is a much-debated question with theoretical frameworks predicting that trade liberalization leads to increase in aggregate productivity and welfare gains (Melitz, 2003). However, empirical frameworks have presented contradicting findings of the impact of trade liberalization. For example, Bresnahan et al. (2016) study the effect of free trade on productivity growth in manufacturing firms of three Sub-Saharan African countries and find no evidence of improved total factor productivity as a result of increased exporting activity. However, proponents of trade liberalization argue that it has the advantage of introducing variety of products and economies of scale in production (Krugman, 1980). Additionally, various studies also show that trade liberalization and exportoriented development strategy is important for developing countries if they are to reap the benefits of international trade. Indeed, Pavcnik (2002) presents empirical evidence of the impact of trade liberalization, showing that it leads to the reallocation of resources from low productivity firms to high productivity firms. Similarly, Melitz (2003) model clearly illustrates how trade fosters only the more productive firms to engage in international trade while the less productive ones continue to sell products in the domestic market. Further, empirical evidence shows that exposure to international trade leads to productivity gains (Esaku, 2019a, 2019b; Esaku, 2020a, 2020b), with continued participation creating opportunities for firms to invest in production technologies (Esaku and Krugell, 2020; Esaku, 2020b, 2020c). This provides evidence that exposure to trade has some positive effects on firms that engage in international trade.

In this paper, using firm-level data from Kenya, we study the effect of trade liberalization on firm-level productivity in the Kenyan manufacturing sector during the period 1992-1999. Kenya, a small African country is chosen because of the following: First, Kenya has carried out a number of structural and macroeconomic reforms that addressed the bottlenecks to trade and economic growth since independence (Ryan and O'Brien, 2001), which is why it forms an appropriate case study. Most of these trade reforms were carried out in three phases; phase one was for period 1980 to 1984, followed by phase two, which took place between 1985 and 1991, and finally, the third phase was from 1992 to 1995. Second, this paper makes the use of import duties $^{1}$ as a percentage of total imports, as a measure of trade liberalization. This measure is available for Kenya spanning eight years, while most African countries having missing or incomplete data on this measure. Between 1989 and 1995, Kenya's development plan hinged on export promotion strategy anchored on the premise of reducing and restructuring of tariffs, abolition of export duties, improving foreign exchange regulation and reforming of trade institutions (Bigsten, 2002). Therefore Kenya offers a good example of an African country that

\footnotetext{
${ }^{1}$ We use import duties and import tariffs or tariffs interchangeably; they have same interpretation in this paper
} 
ESAKU, KRUGELL Trade Liberalization and Productivity Growth in Kenya

successfully implemented trade reform, and would be ideal for studying the effect of trade liberalization on firm productivity growth.

In this paper, we examine the effect of trade liberalization on firm-level productivity following two steps. In the first step, we derive a productivity measure for individual firms using the Levinsohn and Petrin (2003) econometric methodology that generates consistent and reliable estimates of the production function indices. Further, using the correct identification strategy, we identify trade variables to facilitate the econometric analysis. In the second step, we analyze the effect of liberalizing trade on firm-level productivity using import duties as a percentage of total imports as our measure of trade openness. We use import duties as a direct measure of import tariff and examine how it affects firm-level productivity. Aware of the criticisms of using other measures of trade reform, like trade ratios, we use a unique measure of import duties as a percentage of total imports because this is viewed as the most direct measure of trade restrictions (David, 2007). Countries that are more protectionists would rather restrict the import flows into the country than restrict the flow of exports outside of the country. In other words, trade restrictions are mostly imposed on imports rather than on exports. Moreover, the use of import duties is backed by theory and it captures outcomes, policy and the effect of protection on $\operatorname{trade}^{2}$ (David, 2007).

This paper makes a contribution to the literature on the effect of trade on firm-level productivity as was first discussed in the Melitz (2003) model. This line of literature examines the role of international trade in stimulating productivity growth and within firm and industry re-allocation of resources. The Melitz (2003) model emphasizes how exposure to trade induces only the more productive firms to initiate entry into the export markets while the less productive ones continue to serve the home market or are forced out of the market altogether. Furthermore, this paper addresses the methodological issues that plagued previous studies examining the effect of trade policy on productivity growth. Previous research that examined the effect of trade liberalization on total factor productivity growth, suggested that causality was attributed simply by association whereby, if there is observed increase in total factor productivity in the post-liberalization period, then such increase should have been caused by trade liberalization (Chand and Sen, 2002). We address this methodological by using a generally accepted measure of tariff protection- import duties as percentage of total imports, as a measure of trade protection to analyze how changes in trade policy effect productivity growth. Earlier studies that used other measures of trade protection, like openness index, black market premium, import penetration ratios, dollar indexes and other measures were criticized as not backed by economic theory and their failure to capture the effect of policy changes on trade (David, 2007).

This paper is similar to Pavcnik (2002) who studies trade liberalization, exit and productivity improvements in Chilean plants, and Njikam and Cockburn (2011) who study trade

\footnotetext{
${ }^{2}$ This classification is from Wacziarg (1998) broad categorization of measures of trade openness.
} 
liberalization and productivity growth in Cameroon. The major difference in this paper is that we study a different context in which trade liberalization was carried out and we use a different measure of trade liberalization. Besides, Pavcnik (2002) considers exiting firms, which we omit in the analysis due to limitations in our data.

The rest of the paper is organized as follows; section 2 presents review of related literature. Section 3 provides an overview of the data. Section 4 presents empirical framework and econometric methods. Section 5 discusses the results. Section 6 concludes.

\section{Review of Related Literature}

\subsection{Overview of Trade Reform Episodes in Kenya}

After Kenya received its independence in 1963, much of what became its industrial and trade policy was largely designed to promote import substitution (Swamy, 1994). The manufacturing sector was still predominantly tailored towards agro-processing, with little or no capital stock and skilled labor force in place. As noted by Gertz (2008), the government embarked on a process of developing the manufacturing sector by attracting the much needed foreign capital. Government effort to persuade foreign investors to 'set up shop' in the country paid off when businesses like Del Monte, Lonrho, and Firestone eventually set up their businesses in the country (Bigsten, 2002). The above businesses enjoyed government subsidies and tax incentives that helped them raise the productivity of the manufacturing sector by nearly $44 \%$ between 1964 and 1969 (World Bank, 2007).

However, between 1970 and 1971, the country suffered its first balance of payment crisis which worsened in the aftermath of the first oil shock of 1973 leading to the overall decline in the economic performance of the country. To restore macroeconomic stability, the government strengthened the policy of import substitution, erecting trade barriers in the process. The protection of local industries was a common practice in most of the sectors. Consequently, the manufacturing sector expanded by nearly $25 \%$ (World development indicators, 2007), and exports increased substantially following the rise in coffee prices between 1975 and 1977 (Bevan et al., 1999). However, by 1980 coffee prices in the world market plummeted and the performance of the country's economy worsened prompting calls for trade reforms (Gertz, 2008). Moreover, the import substitution strategy that was adopted by the government was biased against the success of exports. However, the import substitution strategy hit a snag when the domestic demand of goods and services dropped as a result of the poor performance of the economy during the 1980s. Additionally, government protection of local industries created monopoly tendencies within these industries (Gertz, 2008), leading to incidences of inefficiencies and general rise in consumer prices. Given the above bottlenecks to economic progress, the country faced serious foreign exchange rate crisis, leading to more government control of the economy to try to restore economic stability. Government controls included high 
ESAKU, KRUGELL Trade Liberalization and Productivity Growth in Kenya

import tariffs and price controls (Bigsten et al. 2010), which further undermined any effort to revive exports and open up the economy for international trade. The share of manufactured exports as percentage of gross domestic products (GDP) dropped, which eventually led to further calls for trade reforms.

Consequently, the country initiated three phases of trade reforms as part of the structural adjustment program (SAP) under the guidance of the World Bank and International Monetary Fund (IMF), leading to the start of trade liberalization process (Ryan and O'Biren, 2001. The first phase was implemented between 1980 and 1984. This first phase involved elimination of market distortions and allowing competition in the domestic economy by phasing out public sector monopoly in the provision of goods and services. During this period, the supply of agricultural inputs, credit and foreign exchange was privatized and placed in the hand of the private sector (Ryan and O'Biren, 2001). There was also a realization of the important contribution of the private sector in driving economic growth. Some of the state-owned commercial enterprises were privatized as a result. The second phase was implemented from 1985 to 1991. During this second phase, the structural adjustment program (SAPs) promoted the elimination of obstacles to international trade and foreign direct investment (FDI) leading to the promotion of export-led development strategy in the country (Ryan and O'Brien, 2001). Import substitution strategy was now replaced with export-led growth, which involved relaxing protection and control of the economy by adopting a flexible exchange rate strategy, easing access to foreign exchange and improving export promotion schemes through export compensation and insurance schemes.

The third phase was between 1992 and 1995 involving additional reforms that covered full liberalization of the economy, including institutional and social reforms as well (Ryan and O'Brien, 2001). During this period, government also liberalized imports so that goods and services previously imported through quotas were allowed to enter the country without quota restrictions. Furthermore, government also prioritized the reduction of import tariffs and elimination of taxes on exports. By 1995, it is believed that Kenya had fully implemented important trade reforms aimed at kick-starting the economy (Odhiambo and Otieno, 2005) and during the same period, the country joined the World Trade Organization (WTO) as a new member.

We show the trend of import duties (\% imports), trade openness and index of financial freedom for the Kenyan economy in Figure 1. We observe that for the period 1984-1991, import duties (labeled as tariffs in figure 1) have been declining; with a further decline in 1993. After the decline in import duties (\% of imports) in 1993, there was a slight rise in 1994, before stabilizing between 1995 and 1998. We also note a marked increase in the opening up of the economy between 1991 and 1993, signaling the trade liberalization episode. Analysis of the financial freedom index also shows similar trend that signal the opening up of the economy for free trade. 
Figure 1: The Evolution of Import Duties (\% of Imports), Trade Openness and Financial Freedom Index, 1984-1999

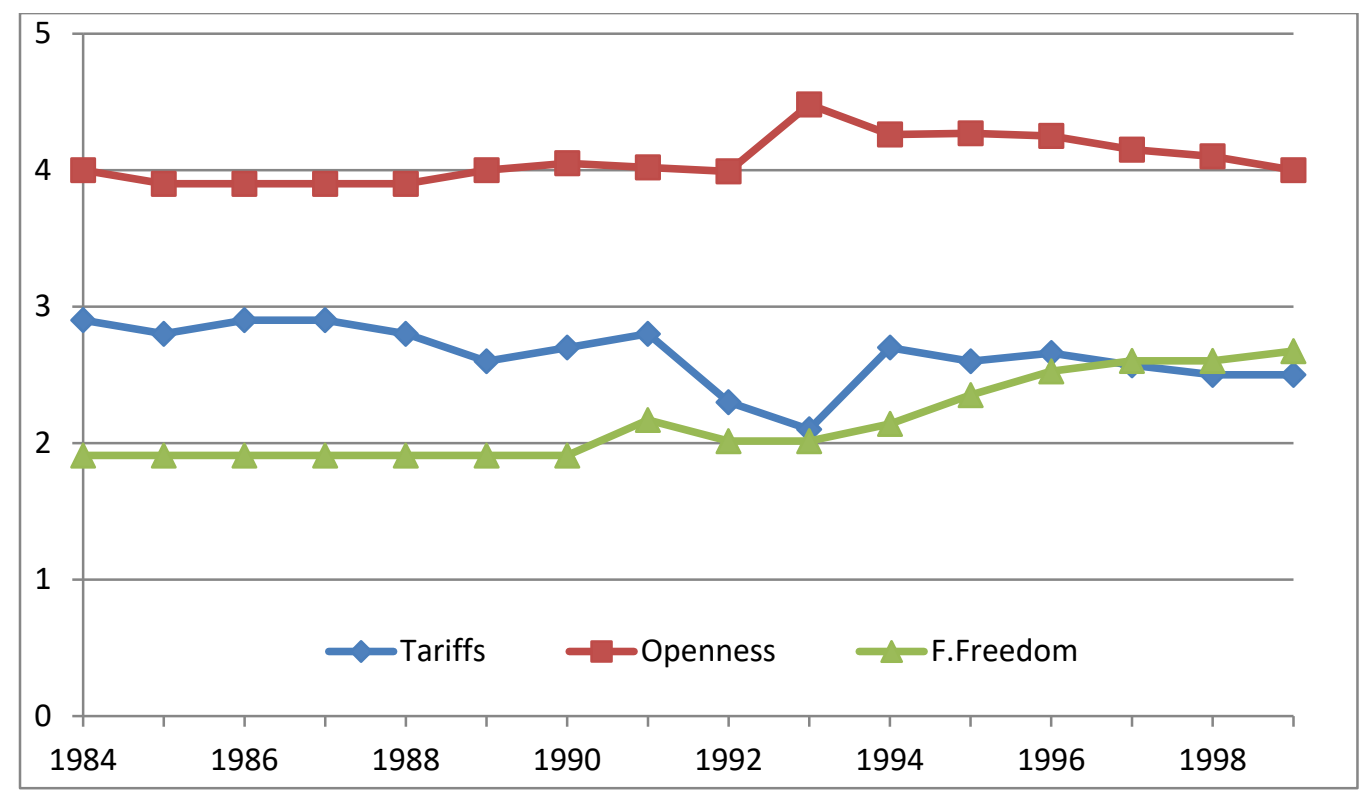

Source: Author calculations from CSAE dataset. Note: Tariffs is import duties ( $\%$ of imports), openness is index of trade openness (sum of exports and imports as \% of GDP), F. Freedom is index of financial freedom. All the three variables are in logs.

\subsection{Trade Liberalization and Firm-Level Productivity}

The effect of trade liberalization on productivity of firms is widely studied, using both theoretical models and empirical analysis. Several theoretical models predict that exposure to trade increases total productivity and shuffling of resources from the least productive firms to more productive ones, resulting into welfare gains (Melitz, 2003). Correspondingly, Melitz and Ottaviano (2008) model indicates how trade liberalization increases product variety, as a result of competition, which lowers prices for consumers thereby generating increased benefits from a combination of improved productivity, lower prices and increased product variety. This clearly shows that liberalizing trade has benefits for the trading partners- by improving the productivity of firms and providing a variety of tradable goods to consumers of a given country. Similarly, trade liberalization may induce reshuffling of production within a firm in response to a reduction in tariffs. Firms may rationalize their production processes and resources by reorganizing their plants in order to produce a limited variety of products.

In the same vein, Bernard et al. (2010) present a model of international trade featuring selfselection and show that trade liberalization induces within firm and between firm reshuffling 
ESAKU, KRUGELL Trade Liberalization and Productivity Growth in Kenya

of resources to strengthen firm productivity. Their model also emphasizes the fact that reallocation of resources occurs not only within and between firms, but may extend to between products and export destinations. Additionally, theoretical models also show that trade liberalization provides trading firms with technology advantage which would otherwise be lacking if firms remain serving the domestic market. Firms that serve foreign markets receive productivity benefits as a consequence of access to better inputs and technology of production that raises technical efficiency (Rivera-Batiz and Romer, 1991).

On the empirical side, Pavcnik (2002) studies the effect of liberalized trade on plant productivity and finds evidence of productivity improvements. Her findings establish that the overall productivity improvements are derived from the reshuffling of resources from the least to the most productive firms. Additionally, international trade reform stimulates competition, where plants respond by trimming off their production process leading to within plant productivity improvements. Pavcnik (2002) study clearly demonstrates how trade reform may cause firms to reorganize their production processes and rationalize input use so as to maximize output and aggregate benefits from trade reform. Moreover, trade liberalization increases overall productivity when the least productive firms are forced out of the industry and productivity adjustment mechanisms raise productivity draw (Ha and Liu, 2014). Relatedly, Amiti and Konings (2007) study the effect of tariff reduction on intermediate inputs and final goods, and present evidence showing that reducing input tariffs significantly increases productivity of firms operating in the industry.

Similarly, lowering of output tariffs has the effect of increasing productivity by stimulating tougher import competition. Furthermore, Lileeva (2008) examines the effect of United States of America (USA) and Canadian tariff cuts on productivity dynamics of firms and finds evidence that tariff cuts increased exit rates among low productivity firms and resource reallocation from low productivity firms to high productivity firms. Most importantly, new export entrants received greater productivity improvement as a consequence of the reduction in tariffs. Accordingly, Liveela and Trefler (2010) study the effect of Canada-U.S. Free Trade Agreement (FTA) and find evidence of within-plant labor productivity in Canadian manufacturing and reshuffling of resources from low productivity firms to high productivity firms. Moreover, firms that have better access to international markets show promising signs of engaging simultaneously in exporting and investing in technology as also shown by Esaku and Krugell (2020), raising their productivity further as a consequence.

In a related argument, Esaku (2020b) demonstrates that small firms that enter foreign markets due to lowering of trade costs increase the productivity as a consequence of export market participation. The above author emphasizes the importance of export market 
participation for firm-level productivity growth. Participation in export markets is one channel through which small firms can raise their productivity (Esaku, 2020c). Given the above, there is evidence that the lowering of tariffs significantly increases firm-level productivity. However, much of the studies have concentrated on developed and developing countries outside of Africa. Not much attention has been directed on how the lowering of tariffs benefits African economies.

To conclude therefore, various studies have been conducted on trade liberalization and firm productivity across most economies, excluding Africa, but such studies on African economies are scarce, which is why this study will help enhance our knowledge of the effect of trade liberalization on firm productivity and export participation in the context of African economies.

\section{The Data and Descriptive Statistics}

\subsection{Description of the Main Variable}

To provide a clear understanding of the main variables, we present the description of these main variables in Table 1.

Table 1. Descriptive Statistics of the Main Variables Used in the Analysis

\begin{tabular}{|l||l|c|c|c|c|}
\hline Variable & Definition & Mean & $\begin{array}{l}\text { Std. } \\
\text { Dev. }\end{array}$ & $\begin{array}{l}\text { Mean non- } \\
\text { exporters }\end{array}$ & $\begin{array}{l}\text { Mean for } \\
\text { exporters }\end{array}$ \\
\hline \hline Ln(Output) & $\begin{array}{l}\text { Natural logarithm of real output per worker in } \\
\text { US\$ }\end{array}$ & 8.85 & 1.30 & 9.52 & 8.58 \\
\hline Ln(K:L) & $\begin{array}{l}\text { Natural logarithm of real Capital/Labor ratio in } \\
\text { US\$ }\end{array}$ & 3.14 & 4.25 & 9.05 & 2.45 \\
\hline Ln(Labor) & Natural logarithm of number of workers & 3.23 & 1.71 & 4.74 & 2.69 \\
\hline Ln(Materials) & $\begin{array}{l}\text { Natural logarithm of real US\$ of materials per } \\
\text { worker }\end{array}$ & 8.16 & 1.46 & 8.85 & 7.87 \\
\hline $\begin{array}{l}\text { Ln(Other } \\
\text { inputs) }\end{array}$ & $\begin{array}{l}\text { Natural logarithm of real US\$ of other inputs } \\
\text { per worker }\end{array}$ & 6.46 & 1.28 & 7.03 & 6.22 \\
\hline Exports & Dummy=1, if the firm is an exporter in period t & 0.11 & 0.31 & 1 & 0 \\
\hline Ln(Wages) & Natural logarithm of real monthly wages in US\$ & 4.30 & 0.93 & 4.67 & 4.14 \\
\hline Tariff & Import duties (\% of imports), WDI (2002) & 2.51 & 0.20 & 2.50 & 2.52 \\
\hline Openness & Exports plus imports as \% of GDP, WDI (2002) & 4.08 & 0.16 & 4.04 & 4.09 \\
\hline Fin. freedom & Financial freedom index (Ross 2002) & 0.52 & 0.13 & 0.53 & 0.52 \\
\hline $\begin{array}{l}\text { Foreign } \\
\text { ownership }\end{array}$ & $\begin{array}{l}\text { Dummy=1, if firm is owned or has some \% of } \\
\text { foreign ownership }\end{array}$ & 0.15 & 0.36 & 0.36 & 0.13 \\
\hline Firm age & Firm's age in the current period & 20.53 & 13.95 & 22.77 & 20.24 \\
\hline
\end{tabular}

Source: Authors' calculations from CSAE dataset, from 1992-1999 
ESAKU, KRUGELL Trade Liberalization and Productivity Growth in Kenya

\subsection{Description of the Data and Distribution of the Industries}

The empirical analysis is based on strongly balanced panel data from the Kenyan manufacturing firms. The data are from a panel survey of firms operating in the textile industry, wood industry, furniture industry, garment industry, metal and machinery and chemical industry, and food and bakery industry. The data cover a period of Eight years from 1992 to 1999. The data were collected under the Regional Program on Enterprise Development (RPED) organized by the World Bank, jointly by the Center for the study of African Economies (CSAE) ${ }^{3}$ and University of Oxford. The dataset was drawn from comprehensive questionnaires carried out with owners or managers and workers of the sampled manufacturing firms with a view to collecting data that is relevant for firm-level analyses. The dataset is unique in having measures of productivity (labor productivity), capital stock, and employment levels per firm. Capital stock is deflated using a weighted average of national consumer price index and nominal US dollar exchange rate $^{4}$. Human capital stock comprises of the following worker characteristics: age, tenure in current job, education level, and real monthly earnings. Other variables contained in the dataset include real output per worker, the real value of capital per worker, real value of materials, real value of other intermediate inputs, ownership status, firm age, and export status of each firm. This dataset was downloaded from CSAE and contains 3240 observations based on 373 manufacturing firms.

Further, the World Bank constituted important sources for tariff data and other export and import data. ${ }^{5}$ We present the descriptive statistics in Table 2.

Table 2. Distribution of the Industries in the Sample, by to Export Status, 1992-1999.

\begin{tabular}{|l||l|c|c|c|}
\hline Country & Sector & Exporters & Non-exporter & All firms \\
\hline \hline \multirow{5}{*}{ Kenya } & Textile & 0.15 & 0.06 & 0.07 \\
\cline { 2 - 5 } & Garment & 0.08 & 0.19 & 0.19 \\
\cline { 2 - 5 } & Wood & 0.06 & 0.09 & 0.08 \\
\cline { 2 - 5 } & Furniture & 0.11 & 0.16 & 0.15 \\
\cline { 2 - 5 } & Food and Bakery & 0.28 & 0.24 & 0.24 \\
\cline { 2 - 5 } & Metal, Machinery, Chemical & 0.32 & 0.26 & 0.27 \\
\hline
\end{tabular}

Source: Authors' calculations from CSAE data. The table reports means, and columns should sum up to 1

\footnotetext{
${ }^{3}$ We thank the Center for the study of African Economies for making the data available for download for free to researchers. We are grateful to you for this assistance without which, it would not have been possible to conduct this study.

${ }^{4}$ See a full description of the dataset and all the variables on www:csae.ox.ac.uk

${ }^{5}$ Some macroeconomic variables were drawn from the database maintained by Rose (2002), and heritage foundation.
} 
As shown in Table 2, most exporters (32\%) are involved in the metal, machinery and Chemical industry, followed by food and bakery (28\%), textiles (15\%), furniture (11\%), garment (8\%), and finally wood sector has the lowest contribution $(6 \%)$. Similarly, non-exporters are more engaged in metal, machinery and chemical industry (26\%), food and bakery (24\%), furniture $(16 \%)$, garment $(19 \%)$ and finally wood $(9 \%)$ and textile $(6 \%)$ respectively. We can observe that both exporters and non-exporters are heavily involved in metal, machinery and chemical manufacturing activities. This clearly shows how important the sector is in boosting economic growth and development in the Kenya economy.

\subsection{Characteristics of Exporters and Non-Exporters}

Table 3 presents the mean characteristics of non-exporters and exporters for the Kenyan manufacturing sector. In this table, exporters, on average, employ more workers (241), have higher value added per worker (9.5), use more capital per worker (9.4), are older (22.2), have more foreign ownership (0.4), pay higher wages (4.6), use more materials per worker in US\$ (8.8) and other inputs per worker in US\$ (6.9) and hire more skilled workers (9.4) than nonexporters. The evidence above shows that exporting firms possess superior characteristics than non-exporters (Bernard and Jensen, 1999).

Table 3. Characteristics of Exporters and Non-Exporters

\begin{tabular}{|l||c|c|c|}
\hline Characteristics & Non-Exporters & Exporters & All \\
\hline \hline Employment $^{\mathrm{a}}$ & 45 & 241 & 105 \\
\hline Value added per worker $^{\mathrm{b}}$ & 8.6 & 9.5 & 8.9 \\
\hline Capital per worker $^{\mathrm{c}}$ & 8.1 & 9.4 & 8.5 \\
\hline Firm Age $^{\mathrm{d}}$ & 20.4 & 22.2 & 21 \\
\hline Foreign ownership $^{\mathrm{e}}$ & 0.1 & 0.4 & 0.2 \\
\hline Average monthly wage US\$ $^{\mathrm{f}}$ & 4.1 & 4.6 & 4.3 \\
\hline Materials per worker in US\$ $^{\mathrm{g}}$ & 7.9 & 8.8 & 8.2 \\
\hline Other inputs per worker US\$ $^{\mathrm{h}}$ & 6.3 & 6.9 & 6.5 \\
\hline Weighted Average education(skills) $^{\mathrm{i}}$ & 7.9 & 9.4 & 8.4 \\
\hline
\end{tabular}

Source: Calculations from CSAE data. We report the mean values of the characteristics of exporters and non-exporters a: Number of workers currently employed by firm, in log; b:log of real output per worker in US\$(value added per worker); c: log of real US\$ Capital per worker; d: The age of the firm at the time of the survey; e: Ownership status; 1 if owned by foreigners, 0, otherwise; f: log of real monthly wages in US\$; g:log of real materials per worker in US\$; h: log of real other inputs per worker in US\$; i: Weighted firm average of education of employee. 
ESAKU, KRUGELL Trade Liberalization and Productivity Growth in Kenya

\section{Empirical Framework}

In this section, we provide the discussion of the strategy for getting consistent estimates of the production function for measuring productivity. The main contributions for measuring firmlevel total factor product (TFP) have been advanced by Wooldridge (2009), Ackerberg, Caves and Frazer (2015, henceforth ACF), Levinsohn and Petrin (2003, henceforth, LP) and Olley and Pakes (1996, henceforth OP). A novel method is suggested by Olley and Pakes (1996) to address the endogeneity problem and selection bias using a structural method to identification of production functions. The endogeneity issue, in their specification, is addressed using investment to proxy for an unobserved time-varying productivity shock, while the selection problem is addressed using survival probabilities. However, this approach is criticized for not being able to address collinearity issues resulting from the first stage of the estimation process (Ackerberg et al., 2015). Similarly, Levinsohn and Petrin (2003) use a similar method for solving the endogeneity issue by using intermediate inputs to proxy for unobserved productivity shock. In this study, with the help of a Stata code (levpet), we use $\mathrm{LP}^{6}$ approach to derive a measure of firm-level productivity and consider a Cobb-Douglas production function.

Thus, consider a firm with a Cobb-Douglas production function;

$$
Y_{i t}=A_{i t}^{\alpha} L_{i t}^{\beta_{l}} K_{i t}^{\beta_{k}} O_{i t}^{\beta_{o}} M_{i t}^{\beta_{m}}+\varepsilon_{i t}
$$

where $Y_{i t}$ denotes output of firm $i$ at time $t$ which is a function of labor, $L_{i t}$, capital, $K_{i t}$, other intermediate inputs, $O_{i t}$, and materials, $M_{i t} \varepsilon_{i t}$ represents two components: the observable and unobservable components. As shown by Bresnahan et al. (2016), $A_{i t}^{\alpha}$ denotes the initial TFP that is unconditional. Our interest is to examine whether productivity of firm $i$ is a function of trade policy, and provide explanation whether firms that operate in the export market before and after the trade liberalization are different. We follow a three-step estimation approach to estimating the effect of trade policy on firm productivity and performance.

In the first step, we take the natural logarithms of eq. (1) above, and select units so that $\ln \mathrm{A}=1$, we index firms by $i$, with time being $t$. Then we write the estimation model for the production function as:

$$
y_{i t}=\beta_{0}+\beta_{1} l_{i t}+\beta_{2} k_{i t}+\beta_{3} o_{i t}+\beta_{4} m_{i t}+\varepsilon_{i t}
$$

Let $\varepsilon_{i t}$ compose of two components:

$$
\varepsilon_{i t}=\omega_{i t}+\psi_{i t}
$$

\footnotetext{
${ }^{6}$ You can check LP, 2003 for details of their estimation procedure. Thanks to Levinsohn and Petrin for providing us with the Stata code.
} 
Where $\omega_{i t}$ denote the predictable component- in this case, firm i's productivity in time $t$, while $\psi_{i t}$ represent the unpredictable component, for instance, demand changes.

The Levinsohn and Petrin ${ }^{7}$ approach proposes a three-step estimator to address two concerns; selection and endogeneity problems. In the first step, we estimate the coefficients of variables inputs (labor and materials), while in the second step, the use of moment conditions is imposed to estimate capital coefficients, and thirdly, predicting residuals. Following LP, we recover the predicted firm-level productivity estimates and build an index of the firm's total factor productivity (TFP), thus we can then write our estimates as:

$$
\bar{\omega}_{i t}=T F P_{i t}=y_{i t}-\bar{\beta}_{1} l_{i t}-\bar{\beta}_{2} k_{i t}-\bar{\beta}_{3} o_{i t}-\bar{\beta}_{4} m_{i t}
$$

where the bar denotes the recovered productivity estimates from each variable of interest (labor, capital, other inputs and materials.

In the second step, we follow standard estimation method common in the trade liberalization literature ${ }^{8}$ and modify it to our analysis. We seek to understand and explain the effect of trade reform, proxied by import duties (\% of imports) on firm productivity. From both the theoretical and empirical view, substantial literature shows potential determinants of firm productivity, herein referred to as total factor productivity (hence forth TFP). However, we restrict our analysis to differential effects of trade reform on firm-level productivity and the growth of productivity across industries. Specifically, we conduct the econometric analysis in a regression framework, where we regress the recovered firm productivity measures on import duties, export share of output, and firm and industry characteristics. In our baseline specification, we posit that firm-level productivity depends on a number of factors: the import duties ( $\%$ of imports) levied, the size of the firm (proxied by number of employees), the age of the firm, the ownership structure (whether foreign owned or local or state owned), the sector or industry it belongs, and its export intensity (proxied by percentage of output exported). We base our specification on insights drawn from Ackah et al. (2012), and Chand and Sen (2002).

Our baseline estimation equation is given as:

$$
\ln T F P_{i t}=\beta_{0}+\beta_{\tau} \operatorname{tariff}_{i t}+\beta_{\rho} p \exp _{i t}+\sum_{i=1}^{n} Z_{i t}+\eta_{j}+\tau_{t}+\mu_{i t}
$$

where $\ln T F P_{i t}$ is the log of firm-level productivity; $\exp _{i t}$ is the share of output sold to export markets. We also control for firm size, age, and ownership status, indexed by vector $Z_{i t}$. There is evidence to suggest that firm-level productivity decreases with age but increases with size

\footnotetext{
${ }^{7} \mathrm{LP}$ method is discussed in "estimating production functions using inputs to control for unobservable (2003).

${ }^{8}$ See Pavcnick(2002), Schor(2004), Topalova (2004), Amiti and Konings(2007) Fernandes(2007) for details
} 
ESAKU, KRUGELL Trade Liberalization and Productivity Growth in Kenya

and ownership structure, giving a reason to suggest that it is important to control for these factors. The ownership status is an indicator variable equal one if the firm is owned or has some percentage of foreign ownership and zero otherwise. Further, $\eta_{j}$ denotes industry-level fixed effects, while $\tau_{t}$ denotes a time-specific effects that account for economy wide macroeconomic shocks affecting all firms and $\mu_{i t}$ denotes the error term. Our parameter of interest is $\beta_{\tau}$ that denotes the effect of the tariff on the TFP of the firm in period $t$.

We estimate eq. (4), using ordinary least squares (OLS), fixed effects (FE), and quantile regression which gives the distributional effects of tariff on TFP. Further, we also introduce interaction terms to understand the effect of the tariff on export share of the firm, and on industry productivity. We further divide our periods into two, pre-liberalization (period from 1992-1995) and post-liberalization (period from 1996-1999), and interact these periods with the import duties to assess how these periods are affected by the lowering of the tariffs.

Consequently, we estimate variants of eq. (4) where we introduce interaction terms.

Specifically, we estimate the following equations:

$$
\begin{gathered}
\ln T F P_{i t}=\beta_{0}+\beta_{\tau} \text { tariff }_{i t}+\beta_{\rho} \text { pexp }+\beta_{\tau} \text { tariff }_{i t} * \operatorname{pexp}_{i t}+\beta_{\tau} \text { tariff }_{i t} * \eta_{j}+\sum_{i=1}^{n} Z_{i t}+\tau_{t}+\mu_{i t} \\
\ln T F P_{i t}=\beta_{0}+\beta_{\rho} p \exp +\beta_{\tau} \text { tariff }_{i t} * p \exp _{i t}+\beta_{\tau} \text { tariff }_{i t} * \eta_{j}+\sum_{i=1}^{n} Z_{i t}+\tau_{t}+\mu_{i t}
\end{gathered}
$$

where $\Delta \ln T F P_{i t}=\left(\ln T F P_{i t}-\ln T F P_{i t-1}\right)$

\section{Results and Discussion}

\subsection{The Effect of Trade Liberalization on Firm-Level Productivity.}

We report the results of the estimation of the set of equation in Table 3. Models (a), (b) and (c) present the results of OLS, FE, and quantile (median) regression respectively. We note that, for both cases, the effect of reducing import tariff is negative and statistically significant, implying that lower tariffs increase firm-level productivity. In model (a), we observe that a 1-unit reduction in import tariff increases firm-level productivity by 5.7\%, significant at $1 \%$ level.

When we examine model (b), we observe that import tariffs have a significant effect on both the pre-liberalization and post-liberalization periods. For example, we note that a reduction in import tariffs increases firm-level productivity in wood and textile industries by $76 \%$, and $118.2 \%$, significant at $10 \%$ and $5 \%$ respectively. The above results show that liberalizing trade leads to firm-level productivity improvements; providing evidence on the statistically significant effect of a reduction in import duties (tariffs) on firm and industry level productivity. 
This finding is in line with the conventional wisdom that trade liberalization leads to significant gains in productivity and is beneficial for developing countries (Ackah et al., 2012; Melitz, 2003).

To provide further evidence on the effect of import tariffs on firm-level and industry productivity level, we use quantile regression for this purpose, model (c). We can see that a reduction in import tariffs increases firm-level productivity by $83.1 \%$, significant at $5 \%$ level. Furthermore, an analysis of the interaction term between tariff and export share shows that a unit reduction in import tariffs, increases firm-level productivity by $1 \%$, significant are $5 \%$ level. To further ascertain the effect of import tariffs on industrial productivity, we note that this effect varies across industries. The industries that have benefited the most from a reduction in import tariffs include wood, textile, furniture and metal, machinery and chemicals. For example, a unit reduction in import tariffs increases industry level productivity by $23.3 \%$ in the wood industry, $18.9 \%$ in the textile industry, $17.1 \%$ in the furniture, and $8 \%$ in the metals, machinery and chemicals, respectively. All these estimates are significant at $1 \%$ level. Furthermore, we examine how the effect of import tariffs is distributed across the various quantiles. Models (d)-(m) provide a clear indication of how the effect is distributed. We note the effect of import tariffs is concentrated around the $25^{\text {th }}$ and $50^{\text {th }}$ quantiles. We observe that a reduction in import tariffs increases firm-level productivity by $127.3 \%$ and $83.1 \%$ in the $25^{\text {th }}$ and $50^{\text {th }}$ quantiles, all significant at 5\% level. Similarly, this effect is also spread across various industries. For example, in model (j), we observe that a reduction in import tariffs increases firm-level productivity by $13.7 \%$ in metal, machinery and chemicals, $20.7 \%$ in the furniture, $28.9 \%$ in the wood, and $13.5 \%$ in the textile, industries respectively. All these estimates are significant at $1 \%$ level, except for textile industry where significance level is at $10 \%$ level. We find further evidence of the effect of a unit reduction in import tariffs on industrial productivity in the $50^{\text {th }}$ quantile. Model $(\mathrm{k})$ shows that a unit reduction of import tariffs increases productivity level by $8 \%$ in the metal, machinery, and chemicals industry, $17.1 \%$ in the furniture industry, $23.3 \%$ in the wood industry and $18.9 \%$ in the textile industry, respectively. There is evidence that the import tariffs did not create a significant effect on food and bakery, and garment industries.

Our findings seem to indicate that trade liberalization is beneficial for both firm and industrial productivity, with changes in the import tariffs causing productivity improvements. As shown by Melitz (2003), the lowering of tariffs should induce productivity improvements and reallocation of resources from the least productive firms to the most productive ones, as labor gets transferred between these firms. Similar to Melitz (2003) conclusions, is the evidence shown by empirical findings (see Lileeva, 2008; Njikam and Cockburn, 2011) showing that the decline in tariffs leads to reallocation of market share towards the most productive firms and within firm productivity gains. Ackah et al. (2012) find similar results on the effect of tariff 
ESAKU, KRUGELL Trade Liberalization and Productivity Growth in Kenya

reductions on firm-level productivity. Consistent with these findings, our results seem to agree with previous findings on the effect of import tariffs on firm-level productivity improvements.

\subsection{The Effect of Trade Liberalization on Productivity Growth}

Next, we attempt to answer the question of whether liberalizing trade induces firm-level productivity growth. We present the results in Table 5, with models (a)-(m) being labeled as before. The results show that reducing import tariffs significantly raises firm-level productivity growth, between the ranges of $6 \%$ and $8.2 \%$. For example, using OLS, the results indicate that a unit reduction in import tariffs increases productivity growth by $6.2 \%$ annually, all else equal. Similarly, when we use FE, the results indicate that a unit reduction in import tariffs raises productivity growth by $8.2 \%$ per annum. When we examine productivity growth according to industries, we find evidence of productivity growth in metals, machinery and chemicals, food and bakery, wood and textile industry, and no evidence of productivity growth in the garment industry.

We further examine the effect of reduction in import tariffs in the pre and post liberalization periods, on productivity growth. The findings reveal a negative and statistically significant relationship between import tariffs and these periods, implying that a move towards more opening up of the economy leads to increased productivity growth. This finding is consistent with the suggestion that trade restrictions reduce the firms' ability to acquire the much needed intermediate inputs necessary in the production process while opening up the economy for trade is beneficial for trading firms. These findings are consistent with the conclusions in Amiti and Konings (2007) who find that lowering of input tariffs leads to increase in productivity growth. Furthermore, previous studies have shown that industries that experience substantial level of trade reforms benefit more from the opening up of the economy for trade (Mukherjee and Chanda, 2017). Though we cannot precisely determine the level of trade reforms at the industry level due to data limitations, our findings seem to indicate this direction. Differential productivity growth effects at industry level might be explained by differences in the level of exposure to international trade following the lowering down of tariffs (Mukherjee and Chanda, 2017) and differences in the way industries respond to the lowering of import tariffs (Breinlich, 2014). Consistent with the above view, our results seem to indicate that the Kenyan manufacturing industries experienced differential effects as a result of the lowering of the import tariffs.

Overall, productivity growth rates are responsive to changes in import duties, indicating that the reduction in import duties could enhance the firms' ability to acquire the much needed technology and intermediate inputs that facilitate output growth hence total productivity growth as suggested by Olper et al. (2017). These findings establish the importance of trade reform for developing countries, especially those in Africa where manufacturing constitutes a small percentage to Gross Domestic Products. 
Review of Economic Analysis 12 (2020) 439-460

Table 4. The effect of tariff on firm-level productivity

\begin{tabular}{|c|c|c|c|c|c|c|c|c|c|c|c|c|c|}
\hline \multirow[t]{3}{*}{ Variables } & \multirow[t]{2}{*}{ OLS } & \multirow[t]{2}{*}{$\mathrm{Fe}$} & \multicolumn{11}{|c|}{ Quantiles } \\
\hline & & & Median & $10^{\text {th }}$ & $25^{\text {th }}$ & $50^{\text {th }}$ & $75^{\text {th }}$ & $90^{\text {th }}$ & $10^{\text {th }}$ & $25^{\text {th }}$ & $50^{\text {th }}$ & $75^{\text {th }}$ & $90^{\text {th }}$ \\
\hline & (a) & (b) & (c) & (d) & (e) & (f) & (g) & (h) & (i) & (j) & (k) & (1) & $(\mathrm{m})$ \\
\hline Tariff & $\begin{array}{c}-0.057 * * * \\
(0.007)\end{array}$ & $\begin{array}{l}-0.048 \\
(0.192)\end{array}$ & $\begin{array}{c}-0.831^{* *} \\
(0.416)\end{array}$ & $\begin{array}{l}-0.999 \\
(0.702)\end{array}$ & $\begin{array}{c}-1.273 * * \\
(0.580)\end{array}$ & $\begin{array}{c}-0.831^{* *} \\
(0.478)\end{array}$ & $\begin{array}{l}-0.230 \\
(0.693)\end{array}$ & $\begin{array}{c}0.440 \\
(0.879)\end{array}$ & & & & & \\
\hline Export share & $\begin{array}{c}0.045^{* * *} \\
(0.009)\end{array}$ & $\begin{array}{l}0.004 \\
(0.023)\end{array}$ & $\begin{array}{c}0.007 \\
(0.008)\end{array}$ & $\begin{array}{c}0.048 * * * \\
(0.004)\end{array}$ & $\begin{array}{l}-0.016 \\
(0.052)\end{array}$ & $\begin{array}{l}-0.021 \\
(0.061)\end{array}$ & $\begin{array}{c}0.025 \\
(0.045)\end{array}$ & $\begin{array}{l}-0.076 \\
(0.043)\end{array}$ & $\begin{array}{c}0.013 \\
(0.018)\end{array}$ & $\begin{array}{l}-0.006 \\
(0.023)\end{array}$ & $\begin{array}{c}0.001 \\
(0.023)\end{array}$ & $\begin{array}{c}0.024 \\
(0.021)\end{array}$ & $\begin{array}{l}-0.019 \\
(0.016)\end{array}$ \\
\hline $\begin{array}{l}\text { Tariff*export } \\
\text { Share }\end{array}$ & $\begin{array}{l}-0.007^{*} \\
(0.004)\end{array}$ & $\begin{array}{c}0.001 \\
(0.009)\end{array}$ & $\begin{array}{c}-0.010 * * * \\
(0.002)\end{array}$ & $\begin{array}{c}-0.024 * * * \\
(0.002)\end{array}$ & $\begin{array}{c}0.006 \\
(0.021)\end{array}$ & $\begin{array}{c}0.012 \\
(0.023)\end{array}$ & $\begin{array}{l}-0.006 \\
(0.018)\end{array}$ & $\begin{array}{l}0.034^{*} \\
(0.018)\end{array}$ & $\begin{array}{l}-0.002 \\
(0.001)\end{array}$ & $\begin{array}{c}0.001 \\
(0.001)\end{array}$ & $\begin{array}{c}0.001 \\
(0.001)\end{array}$ & $\begin{array}{l}-0.001 \\
(0.001)\end{array}$ & $\begin{array}{l}0.002^{*} \\
(0.001\end{array}$ \\
\hline Tariff*pre-Lib. & $\begin{array}{c}0.020 * * * \\
(0.001)\end{array}$ & $\begin{array}{c}-0.065^{* *} \\
(0.030)\end{array}$ & $\begin{array}{c}0.105 * * * \\
(0.040)\end{array}$ & $\begin{array}{l}0.102^{*} \\
(0.078)\end{array}$ & $\begin{array}{l}0.126^{* *} \\
(0.057)\end{array}$ & $\begin{array}{l}0.102 * * \\
(0.048)\end{array}$ & $\begin{array}{c}0.053 \\
(0.069)\end{array}$ & $\begin{array}{l}-0.018 \\
(0.087)\end{array}$ & $\begin{array}{c}0.006 \\
(0.011)\end{array}$ & $\begin{array}{c}0.005 \\
(0.010)\end{array}$ & $\begin{array}{l}0.025^{* *} \\
(0.008)\end{array}$ & $\begin{array}{c}0.028 * * * \\
(0.008)\end{array}$ & $\begin{array}{l}0.026^{*} \\
(0.014)\end{array}$ \\
\hline $\begin{array}{l}\text { Tariff*post- } \\
\text { Lib. }\end{array}$ & $\begin{array}{c}0.020 * * * \\
(0.002)\end{array}$ & $\begin{array}{c}-0.020^{* *} \\
(0.010)\end{array}$ & $\begin{array}{c}0.002 \\
(0.005)\end{array}$ & $\begin{array}{l}-0.008 \\
(0.010)\end{array}$ & $\begin{array}{l}-0.004 \\
(0.009)\end{array}$ & $\begin{array}{c}0.001 \\
(0.007)\end{array}$ & $\begin{array}{c}0.009 \\
(0.011)\end{array}$ & $\begin{array}{c}0.004 \\
(0.019)\end{array}$ & $\begin{array}{l}-0.005 \\
(0.011)\end{array}$ & $\begin{array}{l}-0.004 \\
(0.010)\end{array}$ & $\begin{array}{c}0.002 \\
(0.007)\end{array}$ & $\begin{array}{c}0.005 \\
(0.010)\end{array}$ & $\begin{array}{c}0.008 \\
(0.018)\end{array}$ \\
\hline $\begin{array}{l}\text { Tariff*Metals } \\
\& \text { Machinery }\end{array}$ & $\begin{array}{c}0.110 * * * \\
(0.029)\end{array}$ & $\begin{array}{l}-0.400 \\
(0.476)\end{array}$ & $\begin{array}{c}-0.080 * * * \\
(0.030)\end{array}$ & & & & & & $\begin{array}{l}-0.021 \\
(0.093)\end{array}$ & $\begin{array}{c}-0.137 * * * \\
(0.049)\end{array}$ & $\begin{array}{l}-0.080^{*} \\
(0.048)\end{array}$ & $\begin{array}{l}0.111^{*} \\
(0.069)\end{array}$ & $\begin{array}{c}0.116 \\
(0.097)\end{array}$ \\
\hline $\begin{array}{l}\text { Tariff*Food \& } \\
\text { Bakery }\end{array}$ & $\begin{array}{c}0.432 * * * \\
(0.022)\end{array}$ & $\begin{array}{l}-0.465 \\
(0.477)\end{array}$ & $\begin{array}{c}0.232 * * * \\
(0.032)\end{array}$ & & & & & & $\begin{array}{c}0.266^{* * *} \\
(0.091)\end{array}$ & $\begin{array}{c}0.201 * * * \\
(0.065)\end{array}$ & $\begin{array}{c}0.232 * * * \\
(0.040)\end{array}$ & $\begin{array}{c}0.332 * * * \\
(0.073)\end{array}$ & $\begin{array}{c}0.383 * * * \\
(0.103)\end{array}$ \\
\hline $\begin{array}{l}\text { Tariff*Furnitur } \\
\text { e }\end{array}$ & $\begin{array}{c}-0.113 * * \\
(0.054)\end{array}$ & $\begin{array}{c}0.181 \\
(0.488)\end{array}$ & $\begin{array}{c}-0.171 * * * \\
(0.034)\end{array}$ & & & & & & $\begin{array}{l}-0.048 \\
(0.091)\end{array}$ & $\begin{array}{c}-0.207 * * * \\
(0.049)\end{array}$ & $\begin{array}{c}-0.171 * * * \\
(0.057)\end{array}$ & $\begin{array}{c}-0.129^{* *} \\
(0.057)\end{array}$ & $\begin{array}{c}-0.151^{* *} \\
(0.074)\end{array}$ \\
\hline Tariff*wood & $\begin{array}{c}-0.077 * * \\
(0.007)\end{array}$ & $\begin{array}{l}-0.760^{*} \\
(0.490)\end{array}$ & $\begin{array}{c}-0.233 * * * \\
(0.043)\end{array}$ & & & & & & $\begin{array}{l}-0.191 \\
(0.158)\end{array}$ & $\begin{array}{c}-0.289 * * * \\
(0.066)\end{array}$ & $\begin{array}{c}-0.233 * * \\
(0.117)\end{array}$ & $\begin{array}{c}-0.169 * * \\
(0.083)\end{array}$ & $\begin{array}{l}-0.111 \\
(0.159)\end{array}$ \\
\hline Tariff*Textile & - & $\begin{array}{c}-1.182 * * \\
(0.630)\end{array}$ & $\begin{array}{c}-0.189 * * * \\
(0.044)\end{array}$ & & & & & & $\begin{array}{c}0.027 \\
(0.121)\end{array}$ & $\begin{array}{c}-0.135^{*} \\
(0.042)\end{array}$ & $\begin{array}{c}-0.189 * * * \\
(0.072)\end{array}$ & $\begin{array}{c}-0.173 * * \\
(0.067)\end{array}$ & $\begin{array}{l}-0.131 \\
(0.129)\end{array}$ \\
\hline $\begin{array}{l}\text { Tariff*Garmen } \\
t\end{array}$ & $\begin{array}{c}0.121 * * * \\
(0.038)\end{array}$ & - & - & & & & & & - & - & - & - & - \\
\hline Firm Size & $\begin{array}{c}0.176^{* * *} * \\
(0.032)\end{array}$ & $\begin{array}{c}-0.269 * * * \\
(0.023)\end{array}$ & $\begin{array}{c}0.205^{* * *} * \\
(0.018)\end{array}$ & $\begin{array}{c}0.260 * * * \\
(0.043)\end{array}$ & $\begin{array}{c}0.174 * * * \\
(0.042)\end{array}$ & $\begin{array}{c}0.209 * * * \\
(0.035)\end{array}$ & $\begin{array}{c}0.140 * * * \\
(0.041)\end{array}$ & $\begin{array}{l}0.108^{*} \\
(0.062)\end{array}$ & $\begin{array}{c}0.246 * * * \\
(0.047)\end{array}$ & $\begin{array}{c}0.176 * * * \\
(0.043)\end{array}$ & $\begin{array}{c}0.205^{* * *} \\
(0.037)\end{array}$ & $\begin{array}{c}0.139 * * * \\
(0.040)\end{array}$ & $\begin{array}{c}0.119 * * \\
(0.061)\end{array}$ \\
\hline Firm Age & $\begin{array}{c}0.002 \\
(0.002)\end{array}$ & $\begin{array}{c}-0.269 * * * \\
(0.101)\end{array}$ & $\begin{array}{c}0.003 \\
(0.001)\end{array}$ & $\begin{array}{l}0.007^{*} \\
(0.003)\end{array}$ & $\begin{array}{c}0.001 \\
(0.003)\end{array}$ & $\begin{array}{c}0.003 \\
(0.003)\end{array}$ & $\begin{array}{c}0.006 \\
(0.003)\end{array}$ & $\begin{array}{l}-0.002 \\
(0.003)\end{array}$ & $\begin{array}{c}0.006 \\
(0.003)\end{array}$ & $\begin{array}{c}0.003 \\
(0.003)\end{array}$ & $\begin{array}{c}0.002 \\
(0.003)\end{array}$ & $\begin{array}{c}0.005 \\
(0.003)\end{array}$ & $\begin{array}{l}-0.001 \\
(0.004)\end{array}$ \\
\hline $\begin{array}{l}\text { Foreign } \\
\text { ownership }\end{array}$ & $\begin{array}{c}0.045 \\
(0.085)\end{array}$ & - & $\begin{array}{l}-0.010 \\
(0.071)\end{array}$ & $\begin{array}{l}-0.313 \\
(0.202)\end{array}$ & $\begin{array}{c}-0.078 \\
(0.117)\end{array}$ & $\begin{array}{c}0.027 \\
(0.131)\end{array}$ & $\begin{array}{c}0.156 \\
(0.154)\end{array}$ & $\begin{array}{c}0.158 \\
(0.222)\end{array}$ & $\begin{array}{c}-0.324 * \\
(0.198)\end{array}$ & $\begin{array}{c}-0.108 \\
(0.139)\end{array}$ & $\begin{array}{l}-0.009 \\
(0.144)\end{array}$ & $\begin{array}{c}0.131 \\
(0.156)\end{array}$ & $\begin{array}{c}0.126 \\
(0.238)\end{array}$ \\
\hline Constant & $\begin{array}{c}8.056^{* * *} \\
(0.195)\end{array}$ & $\begin{array}{c}17.143 * * * \\
(4.374)\end{array}$ & $\begin{array}{c}18.726^{* * *} \\
(5.589)\end{array}$ & $\begin{array}{l}19.623^{*} \\
(10.670)\end{array}$ & $\begin{array}{c}24.373 * * * \\
(7.811)\end{array}$ & $\begin{array}{c}18.712 * * * \\
(6.405)\end{array}$ & $\begin{array}{l}11.121 \\
(9.295)\end{array}$ & $\begin{array}{c}2.980 \\
(11.775)\end{array}$ & $\begin{array}{c}6.251 * * * \\
(0.277)\end{array}$ & $\begin{array}{c}7.226^{* * *} \\
(0.163)\end{array}$ & $\begin{array}{c}7.565^{* * *} \\
(0.121)\end{array}$ & $\begin{array}{c}8.085^{* * *} * \\
(0.160)\end{array}$ & $\begin{array}{c}8.817^{* * * *} \\
(0.273)\end{array}$ \\
\hline R-squared & 0.245 & 0.026 & 0.158 & 0.136 & 0.140 & 0.159 & 0.176 & 0.180 & 0.134 & 0.141 & 0.158 & 0.175 & 0.180 \\
\hline \# Observations & 856 & 856 & 856 & 856 & 856 & 856 & 856 & 856 & 856 & 856 & 856 & 856 & 856 \\
\hline Ind. dummies & Yes & Yes & No & Yes & Yes & Yes & Yes & Yes & Yes & Yes & Yes & Yes & Yes \\
\hline Year dummies & Yes & Yes & Yes & Yes & Yes & Yes & Yes & Yes & Yes & Yes & Yes & Yes & Yes \\
\hline
\end{tabular}

Table 5. The effect of trade liberalization on firm-level productivity growth 
ESAKU, KRUGELL Trade Liberalization and Productivity Growth in Kenya

\begin{tabular}{|c|c|c|c|c|c|c|c|c|c|c|c|c|c|}
\hline \multirow[t]{3}{*}{ Variables } & \multirow{3}{*}{$\begin{array}{l}\text { OLS } \\
\text { (a) }\end{array}$} & \multirow[t]{2}{*}{$\mathrm{Fe}$} & \multicolumn{11}{|c|}{ Quantiles } \\
\hline & & & Median & $10^{\text {th }}$ & $25^{\text {th }}$ & $50^{\text {th }}$ & $75^{\text {th }}$ & $90^{\text {th }}$ & $10^{\text {th }}$ & $25^{\text {th }}$ & $50^{\text {th }}$ & $75^{\text {th }}$ & $90^{\text {th }}$ \\
\hline & & (b) & (c) & (d) & (e) & (f) & $(\mathrm{g})$ & (h) & (i) & (j) & (k) & (1) & $(\mathrm{m})$ \\
\hline Tariff & $\begin{array}{c}-0.062 * * * \\
(0.000)\end{array}$ & $\begin{array}{c}-0.082 * * \\
(0.037)\end{array}$ & $\begin{array}{c}-0.060 * * \\
(0.029)\end{array}$ & $\begin{array}{l}-0.052 \\
(0.122)\end{array}$ & $\begin{array}{l}-0.040 \\
(0.053)\end{array}$ & $\begin{array}{l}-0.060^{*} \\
(0.036)\end{array}$ & $\begin{array}{c}-0.090^{* *} \\
(0.041)\end{array}$ & $\begin{array}{l}-0.041 \\
(0.073)\end{array}$ & & & & & \\
\hline Export share & $\begin{array}{c}0.013 * * \\
(0.003)\end{array}$ & $\begin{array}{l}-0.011 \\
(0.019)\end{array}$ & $\begin{array}{c}-0.037 * * * \\
(0.004)\end{array}$ & $\begin{array}{l}-0.001 \\
(0.027)\end{array}$ & $\begin{array}{c}0.010 \\
(0.017)\end{array}$ & $\begin{array}{l}-0.004 \\
(0.010)\end{array}$ & $\begin{array}{c}0.002 \\
(0.011)\end{array}$ & $\begin{array}{l}0.033^{*} \\
(0.018)\end{array}$ & $\begin{array}{l}-0.001 \\
(0.011)\end{array}$ & $\begin{array}{c}0.004 \\
(0.007)\end{array}$ & $\begin{array}{l}-0.002 \\
(0.004)\end{array}$ & $\begin{array}{c}0.001 \\
(0.004)\end{array}$ & $\begin{array}{l}0.012^{*} \\
(0.007)\end{array}$ \\
\hline Tariff*export & $-0.005 * *$ & 0.004 & 0.001 & 0.000 & $-0.004 * *$ & 0.001 & -0.001 & $-0.013^{*}$ & -0.002 & -0.000 & 0.000 & 0.000 & $-0.001 *$ \\
\hline Share & $(0.001)$ & $(0.007)$ & $(0.002)$ & $(0.010)$ & $(0.001)$ & $(0.004)$ & $(0.004)$ & $(0.007)$ & $(0.001)$ & $(0.001)$ & $(0.000)$ & $(0.000)$ & $(0.000)$ \\
\hline Tariff*pre- & $-0.004 * * *$ & $-0.013 * *$ & $0.005^{* *}$ & -0.000 & 0.003 & $0.006^{*}$ & $0.011 * * *$ & $0.013^{* *}$ & $-0.005^{* * *}$ & -0.001 & -0.001 & $0.003 * * *$ & $0.009 * * *$ \\
\hline Lib. & $(0.000)$ & $(0.006)$ & $(0.002)$ & $(0.011)$ & $(0.005)$ & $(0.003)$ & $(0.004)$ & $(0.006)$ & $(0.001)$ & $(0.001)$ & $(0.001)$ & $(0.001)$ & $(0.002)$ \\
\hline Tariff*post- & $-0.004 * *$ & $-0.006^{* *}$ & $-0.003^{* *}$ & $-0.004^{*}$ & $-0.003^{* * *}$ & $-0.003 * * *$ & $-0.003^{* * *}$ & -0.002 & $-0.004^{*}$ & $-0.003^{* * *}$ & $-0.003^{* * *}$ & $-0.003^{* * *}$ & -0.002 \\
\hline & $(0.000)$ & $(0.003)$ & $(0.000)$ & $(0.002)$ & $(0.001)$ & $(0.000)$ & $(0.001)$ & $(0.001)$ & $(0.002)$ & $(0.001)$ & $(0.001)$ & $(0.0001)$ & $(0.001)$ \\
\hline Tariff*Metals & $-0.010 * *$ & $-1.159 * * *$ & -0.001 & & & & & & -0.005 & -0.002 & -0.000 & -0.004 & -0.001 \\
\hline \& Machinery & $(0.004)$ & $(0.439)$ & $(0.002)$ & & & & & & $(0.009)$ & $(0.006)$ & $(0.003)$ & $(0.004)$ & $(0.007)$ \\
\hline Tariff*Food & $-0.012 * *$ & $-1.172 * * *$ & 0.001 & & & & & & -0.005 & -0.002 & 0.000 & $-0.006^{*}$ & 0.001 \\
\hline \& Bakery & $(0.002)$ & $(0.412)$ & $(0.002)$ & & & & & & $(0.009)$ & $(0.005)$ & $(0.004)$ & $(0.004)$ & $(0.006)$ \\
\hline Tariff*Furnitu & -0.001 & $-0.858 * *$ & 0.004 & & & & & & -0.004 & 0.001 & 0.004 & 0.005 & 0.013 \\
\hline & $(0.006)$ & $(0.464)$ & $(0.002)$ & & & & & & $(0.013)$ & $(0.005)$ & $(0.006)$ & $(0.007)$ & $(0.023)$ \\
\hline Tariff*wood & - & $\begin{array}{c}-0.999 * \\
(0.631)\end{array}$ & $\begin{array}{c}0.012 * * * \\
(0.003)\end{array}$ & & & & & & $\begin{array}{c}0.000 \\
(0.023)\end{array}$ & $\begin{array}{c}0.018^{* *} \\
(0.008)\end{array}$ & $\begin{array}{c}0.012 * * \\
(0.009)\end{array}$ & $\begin{array}{c}0.020^{* *} \\
(0.010)\end{array}$ & $\begin{array}{l}0.021^{*} \\
(0.012)\end{array}$ \\
\hline Tariff*Textile & $\begin{array}{c}-0.008 * * * \\
(0.001)\end{array}$ & $\begin{array}{c}-1.330^{* * *} \\
(0.519)\end{array}$ & $\begin{array}{c}0.010^{* * * *} \\
(0.003)\end{array}$ & & & & & & $\begin{array}{c}0.002 \\
(0.013)\end{array}$ & $\begin{array}{c}-0.020^{* * * *} \\
(0.006)\end{array}$ & $\begin{array}{c}0.021 * * * \\
(0.005)\end{array}$ & $\begin{array}{c}0.001 \\
(0.006)\end{array}$ & $\begin{array}{c}0.009 \\
(0.007)\end{array}$ \\
\hline $\begin{array}{l}\text { Tariff*Garme } \\
\text { nt }\end{array}$ & $\begin{array}{c}0.000 \\
(0.011)\end{array}$ & - & - & & & & & & - & - & - & - & - \\
\hline Firm Size & $\begin{array}{c}0.002 \\
(0.002)\end{array}$ & $\begin{array}{c}-0.136^{* * *} \\
(0.023)\end{array}$ & $\begin{array}{c}0.001 \\
(0.001)\end{array}$ & $\begin{array}{c}0.013^{* *} \\
(0.005)\end{array}$ & $\begin{array}{c}0.007 * * \\
(0.003)\end{array}$ & $\begin{array}{c}0.001 \\
(0.002)\end{array}$ & $\begin{array}{l}-0.005^{*} \\
(0.003)\end{array}$ & $\begin{array}{c}-0.014 * * * \\
(0.004)\end{array}$ & $\begin{array}{c}0.013^{* *} \\
(0.005)\end{array}$ & $\begin{array}{c}0.007 * * \\
(0.003)\end{array}$ & $\begin{array}{c}0.001 \\
(0.002)\end{array}$ & $\begin{array}{l}-0.005^{*} \\
(0.003)\end{array}$ & $\begin{array}{c}-0.014 * * * \\
(0.005)\end{array}$ \\
\hline Firm Age & $\begin{array}{l}-0.000 \\
(0.000)\end{array}$ & $\begin{array}{c}-0.036^{*} \\
(0.020)\end{array}$ & $\begin{array}{c}0.000 \\
(0.000)\end{array}$ & $\begin{array}{c}0.000 \\
(0.001)\end{array}$ & $\begin{array}{c}0.000 \\
(0.001)\end{array}$ & $\begin{array}{c}0.000 \\
(0.000)\end{array}$ & $\begin{array}{c}0.000 \\
(0.000)\end{array}$ & $\begin{array}{c}0.000 \\
(0.001)\end{array}$ & $\begin{array}{l}-0.000 \\
(0.000)\end{array}$ & $\begin{array}{c}0.000 \\
(0.000)\end{array}$ & $\begin{array}{c}0.000 \\
(0.000)\end{array}$ & $\begin{array}{c}0.003 \\
(0.000)\end{array}$ & $\begin{array}{c}0.000 \\
(0.001)\end{array}$ \\
\hline $\begin{array}{l}\text { Foreign } \\
\text { ownership }\end{array}$ & $\begin{array}{c}-0.018 \\
(0.011)\end{array}$ & - & $\begin{array}{l}-0.006 \\
(0.005)\end{array}$ & $\begin{array}{l}-0.021 \\
(0.020)\end{array}$ & $\begin{array}{l}-0.006 \\
(0.010)\end{array}$ & $\begin{array}{l}-0.007 \\
(0.009)\end{array}$ & $\begin{array}{l}0.0 .002 \\
(0.009)\end{array}$ & $\begin{array}{l}-0.000 \\
(0.014)\end{array}$ & $\begin{array}{c}-0.020 \\
(0.023)\end{array}$ & $\begin{array}{l}-0.007 \\
(0.013)\end{array}$ & $\begin{array}{l}-0.006 \\
(0.009)\end{array}$ & $\begin{array}{c}0.003 \\
(0.010)\end{array}$ & $\begin{array}{c}0.000 \\
(0.014)\end{array}$ \\
\hline Constant & $\begin{array}{c}-0.810 * * * \\
(0.0142)\end{array}$ & $\begin{array}{c}2.538 * * * \\
(0.965)\end{array}$ & $\begin{array}{l}0.804^{* *} \\
(0.397)\end{array}$ & $\begin{array}{c}0.621 \\
(1.638)\end{array}$ & $\begin{array}{c}0.493 \\
(0.716)\end{array}$ & $\begin{array}{l}0.804^{*} \\
(0.484)\end{array}$ & $\begin{array}{l}1.252^{* *} \\
(0.556)\end{array}$ & $\begin{array}{c}0.637 \\
(0.995)\end{array}$ & $\begin{array}{c}-0.071 * * * \\
(0.020)\end{array}$ & $\begin{array}{c}-0.044 * * * \\
(0.014)\end{array}$ & $\begin{array}{l}-0.004 \\
(0.012)\end{array}$ & $\begin{array}{c}0.038 * * * \\
(0.014)\end{array}$ & $\begin{array}{c}0.085^{* * *} * \\
(0.024)\end{array}$ \\
\hline R-squared & 0.051 & 0.008 & 0.023 & 0.151 & 0.044 & 0.023 & 0.082 & 0.171 & 0.151 & 0.044 & 0.023 & 0.082 & 0.172 \\
\hline \# Observation & 421 & 421 & 421 & 421 & 421 & 421 & 421 & 421 & 421 & 421 & 421 & 421 & 421 \\
\hline Ind. dummies & No & No & No & Yes & Yes & Yes & Yes & Yes & No & No & No & No & No \\
\hline Yr. dummies & Yes & Yes & Yes & Yes & Yes & Yes & Yes & Yes & Yes & Yes & Yes & Yes & Yes \\
\hline
\end{tabular}




\subsection{Robustness check}

In this section, we provide some robustness checks for our results. First, we examine whether the method of Levinsohn and Petrin (2003) used for identification of the production function yields unbiased results. Some studies have shown that estimating the relationship between trade reform and firm-level productivity yields different results on account of the method used to estimate the production function. Kealey et al. (2019) provide evidence of the sensitivity of the results to different methods used for estimating the production function. Consequently, we use the method proposed by Ackerberg et al. (2015) to calculate the estimates of the production function and then use the recovered estimates of the production function to estimate the change in firm-level productivity. The results are shown in the appendix A. Our results show that there is no substantial difference between the two methods used for estimating the production function, that is, Levinsohn and Petrin (2003) and Ackerberg et al. (2015). We find a negative relationship between import tariffs and total factor productivity (estimated using ACF method). This implies that the lowering of import tariffs leads to an increase in firm-level productivity. This finding gives credence to previous findings based on TFP estimates derived using LP method. However, we find that using ACF method seems to give more statistically significant estimates of productivity at the industry level compared to when we use LP method.

\section{Conclusion}

In this paper, we have examined the effects of trade liberalization on firm-level productivity growth in the Kenyan manufacturing sector using import duties as a percentage of total imports, to proxy trade liberalization. We conduct our analysis in a two-step method. Firstly, we estimate the production function using the method proposed by Levinsohn and Petrin (2003) to derive unbiased productivity estimates of the production function. Secondly, we use various regression methods, OLS, FE and Quantile regression to examine the effect of trade liberalization on firm productivity growth.

Our results are remarkable. First, examining the effects of trade liberalization on firm productivity, we find evidence to support the view that liberalizing trade enhances firm-level productivity in the traded sector. Specifically, using recovered productivity estimates of the production function, we show that increased exposure of Kenya's manufacturing sector to trade generated significant firm-level productivity growth. Across the three regression methods, we find evidence that the lowering of import tariffs has generated increased productivity. However, we observe a differential effect across the industries. We find variability in the way industries have responded to the decline in import tariffs. This is especially true for the garment and food and bakery industries where the effect of the lowering of import tariffs has not increased firmlevel productivity. 
ESAKU, KRUGELL Trade Liberalization and Productivity Growth in Kenya

Our findings have important policy implications for improving the manufacturing sector in Kenya. These findings show that formulating policies that effectively relax restrictive barriers to trade in the economy might speed up firm-level productivity in the manufacturing sector. Whereas these results suggest a positive direction towards increased exposure to trade, this exposure should be accompanied by improved infrastructure and supportive institutions to enforce contracts. One limitation of this study is that the data we use seem to be old. Several changes might have taken place in the Kenyan economy, which implies that recent data is now needed to test the debates surrounding trade liberalization.

\section{References:}

Ackah, C., Aryeetey, E., and Morrissey, O. (2012). Tariffs and Total Factor Productivity: The Case of Ghanaian Manufacturing Firms. Modern Economy, 3:275-283. doi:10.4236/me.2012.33037

Ackerberg, D. A., Caves, K., and Frazer, G. (2015). Identification Properties of Recent Production Function Estiators. Econometrica, 83(6):2411-2451

Amiti, B. M., and Konings, J. (2007). Trade Liberalization , Intermediate Inputs , and Productivity: Evidence from Indonesia. American Economic Review, 97(5): 1611-1638. doi:10.1257/aer.97.5.1611

Bernard, A.B., and Jensen, J.B. (1999). Exceptional exporter performance: cause, effect, or both?. Journal of International Economics, 47, 1-25.

Bernard, A. B., Redding, S. J., and Schott, P. K. (2010). Multi-Product Firms and Trade Liberalization. Quarterly Journal of Economics 126 (3): 1271-1318. doi:10.1093/qje/qjr021.

Bevan, D., Collier, P., and Gunning, J.W. (1999). Anatomy of a Temporary Trade Shock: The Kenyan Coffee Boom of 1976-79. In P. Collier and J.W. Gunning, Trade Shocks in Developing Countries, (eds) Oxford: Oxford University Press.

Bigsten, A. (2002). History and Policy of Manufacturing in Kenya. In A. Bigsten, and P. Kimuyu (eds), Structure and Performance of Manufacturing in Kenya. New York: Palgrave Bigsten, A., Kimuyu, P., and Söderbom, M. (2010). The Manufacturing Sector. In C. Adams, P. Collier, and N.S. Ndungu (eds), Kenya: Policies for Prosperity. Oxford: Oxford University Press

Breinlich, H. (2014). Heterogeneous firm-level responses to trade liberalization: A test using stock price reactions. Journal of International Economics, 93(2): 270-285. doi:10.1016/j.jinteco.2014.04.002

Bresnahan, L., Coxhead, I., Foltz, J., and Mogues, T. (2016). Does Freer Trade Really Lead to Productivity Growth? Evidence from Africa. World Development, 86: 18-29. doi:10.1016/j.worlddev.2016.05.007 
Review of Economic Analysis 12 (2020) 439-460

Chand, S., and Sen, K. (2002). Trade Liberalization and Productivity Growth : Evidence from Indian Manufacturing. Review of Development Economics, 6(1): 120-132. doi:10.1111/1467-9361.00145

David, H. L. (2007). A Guide to Measures of Trade Openness and Policy. Available at: https://www.scribd.com/document/312886737/A-Guide-to-Measures-of-Trade-Openness-andPolicy

Esaku, S. (2019a). Trade liberalization, firm dynamics and export market participation in SubSaharan Africa. PhD Thesis, North-West University Press, South Africa.

Esaku, S. (2019b). Exports and Firm Productivity in Sub-Saharan Africa. Journal of African Business. $4^{\text {th }}$. Dec. 2019 https://doi.org/10.1080/15228916.2019.1695190.

Esaku, S. (2020a). Does firm size affect learning-by-exporting? Empirical evidence from SubSaharan Africa. Cogent Economics \& Finance, 8(1): 1754150. https://doi.org/10.1080/23322039.2020.1754150

Esaku, S. (2020b). Investments, export entry and export intensity in small manufacturing firms. Journal of Industrial and Business Economics, 47:677-697. https://doi.org/10.1007/s40812$\underline{020-00156-9}$

Esaku, S. (2020c). Exports, Investment and Productivity Growth in Small Firms: A Firm-level Analysis from Tanzania and Ghana. Journal of African Business, 1-23. https://doi.org/10.1080/15228916.2020.1838836

Esaku, S., and Krugell, F.W. (2020). Firm-Level Investment and Exporting: New Empirical Evidence from Ghana and Tanzania. International Economic Journal, 34(1):125-143. https://doi.org/10.1080/10168737.2019.1663440

Gertz, G.(2008). Kenya's Trade Liberalization of the 1980s and 1990s: Policies, Imports, and Implications. Background Paper to The Impact of the Doha Round on Kenya. Available at: http://www.carnegie endowment.org/files/impact_doha_kenya.pdf

Hu, A. G., \& Liu, Z. (2014). Trade Liberalization and Firm Productivity: Evidence from Chinese Manufacturing Industries. Review of International Economics, 22(3): 488-512. doi:10.1111/roie.12127

Kealey, J., Pujolas, P.S., \& Sosa-Padilla, C. (2019). Trade Liberalization and Firm Productivity: Estimation methods matter. Economic Inquiry, 57(3): 1272-1283.doi:10.1111/ecin.12767

Krugman, P. (1980). Scale economies, product differentiation, and the pattern of trade. American Economic Review, 70(5): 950-959. doi:10.2307/1805774

Levinsohn, J. Petrin, A. (2003). Estimating Production Functions Using Inputs to Control for Unobservables Estimating Production Functions Using Inputs to Control for Unobservables. Review of Economic Studies, 70(2): 317-341. doi:10.1111/1467-937X.00246

Lileeva, A. (2008). Trade Liberalization and Productivity Dynamics: Evidence from Canada. Canadian Journal of Economics, 41(2): 360-390. doi:10.1111/j.1540-5982.2008.00467.x 
ESAKU, KRUGELL Trade Liberalization and Productivity Growth in Kenya

Lileeva, A., \& Trefler, D. 2010. Improved Access to Foreign Markets Raises Plant Plant-level productivity ... for some Plants. Quarterly Journal of Economics, 125(3):1051-1099. doi:10.1162/qje.2010.125.3.1051

Melitz, M.J. (2003). The Impact of Trade on Intra-Industry Reallocations and Aggregate Industry Productivity. Econometrica, 71(6): 1695-1725. doi:10.1111/1468-0262.00467

Melitz, M. J., \& Ottaviano G.I.P. (2008). Market Size, Trade, and Productivity. Review of Economic Studies, 75:295-316. doi:10.1111/j.1467-937X.2007.00463.x

Mukherjee, S. \& Chanda, R. (2017). Differential effects of trade openness on Indian manufacturing firms. Economic Modelling, 61: 273-292. doi:10.1016/j.econmod.2016.10.001

Njikam. O., \& Cockburn. J.(2011). Trade Liberalization and Productivity Growth: Firm-Level Evidence from Cameroon. Journal of Developing Areas, 44(2):279-302. doi: $10.1353 /$ jda. 0.0103

Odhiambo, W., \& Otieno, G. (2005). Trade Policy Reforms and Poverty in Kenya: Processes and Outcomes. A background Paper prepared for the Policy Round Table discussion on the Linkages between Trade, Development and Poverty Reduction. Available at: http://www.cuts-citee.org/pdf/backgrounder-kenya.pdf

Olley, G.S., \& Pakes, A. (1996). The Dynamics of Productivity in the Telecommunications Equipment Industry. Econometrica, 64(6):1263-1297.

Olper, A., Curzi, D., \& Raimondi, V. (2017). Imported Intermediate Inputs and Firms' Productivity Growth: Evidence from the Food Industry. Journal of Agricultural Economics, 68(1):280-300. doi: 10.1111/1477-9552.12164.

Pavcnik, N. (2002). Trade Liberalizat on, Exit, and Productivity Improvements : Evidence from Chilean Plants. Review of Economic Studies, 69(1): 245-276. doi:10.1111/1467937X.00205

Rivera-Batiz, L. \& Romer, P. (1991). Economic Integration and Endogenous Growth. Quarterly Journal of Economics, 106(2):531-555. doi:10.2307/2937946

Ryan, T.C.I \& O'Brien, F.S. (2001). Kenya country case study. In Devarajan, S. , Dollar, R. D. \& Holmgren, T(eds), Aid and Reform in Africa, World Bank, Washington D.C

Swamy, G. (1994). Kenya: Structural Adjustment in the 1980s. World Bank Policy Research Working Paper 1238. Washington, D.C. World Bank

Wooldridge, J. (2009). On estimating firm-level production functions using proxy variables to control for unobservables. Econ Letters 104:112-114. doi:10.1016/j.econlet.2009.04.026

World Bank (2002). World Development Indicators 2002. Washington, D.C

World Bank (2007). World Development Indicators 2007. Washington, D.C 
Review of Economic Analysis 12 (2020) 439-460

Appendix A: Robustness Checks

Table A-1: The effect of trade liberalization on firm-level productivity (ACF method)

\begin{tabular}{|c|c|c|c|c|c|c|c|c|c|c|c|c|c|}
\hline \multirow[t]{3}{*}{ Variables } & \multirow[t]{2}{*}{ OLS } & \multirow[t]{2}{*}{$\mathrm{Fe}$} & \multicolumn{11}{|l|}{ Quantiles } \\
\hline & & & Median & $10^{\text {th }}$ & $25^{\text {th }}$ & $50^{\text {th }}$ & $75^{\text {th }}$ & $90^{\text {th }}$ & $10^{\text {th }}$ & $25^{\text {th }}$ & $50^{\text {th }}$ & $75^{\text {th }}$ & $90^{\text {th }}$ \\
\hline & (a) & (b) & (c) & (d) & (e ) & (f) & (g) & (h) & (i) & (j) & (k) & (1) & (m) \\
\hline Tariff & $\begin{array}{c}-0.057 * * * \\
(0.007)\end{array}$ & $\begin{array}{c}0.007 \\
(0.202)\end{array}$ & $\begin{array}{c}-0.361 * * \\
(0.493)\end{array}$ & $\begin{array}{l}-0.658 \\
(0.928)\end{array}$ & $\begin{array}{c}-1.231 * * \\
(0.664)\end{array}$ & $\begin{array}{c}-0.540 * * \\
(0.331)\end{array}$ & $\begin{array}{l}-0.324 * \\
(0.204)\end{array}$ & $\begin{array}{c}0.647 \\
(1.091)\end{array}$ & & & & & \\
\hline Export share & $\begin{array}{c}0.012 \\
(0.013)\end{array}$ & $\begin{array}{c}0.008 \\
(0.024)\end{array}$ & $\begin{array}{c}0.007 \\
(0.025)\end{array}$ & $\begin{array}{c}0.013 \\
(0.020)\end{array}$ & $\begin{array}{l}-0.006 \\
(0.022)\end{array}$ & $\begin{array}{l}-0.002 \\
(0.027)\end{array}$ & $\begin{array}{c}0.021 \\
(0.018)\end{array}$ & $\begin{array}{l}-0.019 \\
(0.020)\end{array}$ & $\begin{array}{c}0.081 \\
(0.019)\end{array}$ & $\begin{array}{l}-0.008 \\
(0.022)\end{array}$ & $\begin{array}{c}0.015 \\
(0.025)\end{array}$ & $\begin{array}{l}0.021^{*} \\
(0.016)\end{array}$ & $\begin{array}{l}-0.009 \\
(0.018)\end{array}$ \\
\hline $\begin{array}{l}\text { Tariff*export } \\
\text { Share }\end{array}$ & $\begin{array}{l}-0.004 \\
(0.005)\end{array}$ & $\begin{array}{l}-0.001 \\
(0.009)\end{array}$ & $\begin{array}{c}0.005 \\
(0.010)\end{array}$ & $\begin{array}{l}-0.023^{*} \\
(0.011)\end{array}$ & $\begin{array}{c}0.001 \\
(0.001)\end{array}$ & $\begin{array}{c}0.005 \\
(0.002)\end{array}$ & $\begin{array}{l}-0.001 \\
(0.001)\end{array}$ & $\begin{array}{c}0.002 \\
(0.002)\end{array}$ & $\begin{array}{c}0.001 \\
(0.001)\end{array}$ & $\begin{array}{c}0.001 \\
(0.002)\end{array}$ & $\begin{array}{c}0.001 \\
(0.001)\end{array}$ & $\begin{array}{l}-0.001 \\
(0.001)\end{array}$ & $\begin{array}{c}0.002 \\
(0.002)\end{array}$ \\
\hline Tariff*pre- & $0.020 * * *$ & $-0.092 * * *$ & 0.059 & 0.065 & $0.123 * *$ & $0.074^{*}$ & 0.053 & -0.040 & -0.002 & 0.006 & $0.024 * *$ & $0.024 * * *$ & $0.024 * *$ \\
\hline Lib. & $(0.001)$ & $(0.031)$ & $(0.048)$ & $(0.097)$ & $(0.064)$ & $(0.042)$ & $(0.062)$ & $(0.107)$ & $(0.001)$ & $(0.009)$ & $(0.009)$ & $(0.009)$ & $(0.012)$ \\
\hline $\begin{array}{l}\text { Tariff* post- } \\
\text { Lib. }\end{array}$ & $\begin{array}{c}0.032 * * * \\
(0.002)\end{array}$ & $\begin{array}{c}-0.020 * * \\
(0.010)\end{array}$ & $\begin{array}{c}0.006 \\
(0.007)\end{array}$ & $\begin{array}{l}-0.010 \\
(0.010)\end{array}$ & $\begin{array}{l}-0.002 \\
(0.008)\end{array}$ & $\begin{array}{c}0.006 \\
(0.007)\end{array}$ & $\begin{array}{c}0.006 \\
(0.009)\end{array}$ & $\begin{array}{c}0.024 \\
(0.021)\end{array}$ & $\begin{array}{c}-0.011 * * * \\
(0.001)\end{array}$ & $\begin{array}{l}-0.001 \\
(0.010)\end{array}$ & $\begin{array}{c}0.006 \\
(0.009)\end{array}$ & $\begin{array}{c}0.008 \\
(0.010)\end{array}$ & $\begin{array}{c}0.024 \\
(0.018)\end{array}$ \\
\hline $\begin{array}{l}\text { Tariff*Metals } \\
\& \text { Machinery }\end{array}$ & $\begin{array}{c}0.123 * * * \\
(0.031)\end{array}$ & $\begin{array}{l}-0.500 \\
(0.500)\end{array}$ & $\begin{array}{c}-0.087 * * \\
(0.036)\end{array}$ & & & & & & $\begin{array}{l}-0.003 \\
(0.095)\end{array}$ & $\begin{array}{c}-0.109^{* *} \\
(0.054)\end{array}$ & $\begin{array}{l}-0.087^{*} \\
(0.053)\end{array}$ & $\begin{array}{c}0.035 \\
(0.064)\end{array}$ & $\begin{array}{c}0.050 \\
(0.100)\end{array}$ \\
\hline Tariff*Food & $0.448 * * *$ & -0.492 & $0.220 * * *$ & & & & & & $0.253 * * *$ & $0.198 * * *$ & 0.221 & $0.321 * * *$ & $0.419 * * *$ \\
\hline \& Bakery & $(0.026)$ & $(0.501)$ & $(0.038)$ & & & & & & $(0.092)$ & $(0.060)$ & $(0.015)$ & $(0.076)$ & $(0.092)$ \\
\hline $\begin{array}{l}\text { Tariff*Furnitu } \\
\text { re }\end{array}$ & $\begin{array}{l}-0.034 \\
(0.051)\end{array}$ & $\begin{array}{c}0.120 \\
(0.513)\end{array}$ & $\begin{array}{c}-0.159^{* * *} \\
(0.041)\end{array}$ & & & & & & $\begin{array}{l}-0.045 \\
(0.094)\end{array}$ & $\begin{array}{c}-0.158^{* * *} \\
(0.058)\end{array}$ & $\begin{array}{c}-0.158^{* * *} \\
(0.057)\end{array}$ & $\begin{array}{c}-0.151^{* * *} \\
(0.056)\end{array}$ & $\begin{array}{c}-0.212 * * * \\
(0.074)\end{array}$ \\
\hline Tariff*wood & $\begin{array}{l}-0.053 \\
(0.046)\end{array}$ & $\begin{array}{l}-0.777 \\
(0.620)\end{array}$ & $\begin{array}{c}-0.235^{* * * *} \\
(0.050)\end{array}$ & & & & & & $\begin{array}{l}-0.136 \\
(0.140)\end{array}$ & $\begin{array}{c}-0.278 * * * \\
(0.075)\end{array}$ & $\begin{array}{c}-0.235^{* * * *} \\
(0.077)\end{array}$ & $\begin{array}{c}-0.192 * * \\
(0.093)\end{array}$ & $\begin{array}{l}-0.112 \\
(0.134)\end{array}$ \\
\hline Tariff*Textile & - & $\begin{array}{c}-1.295^{* *} \\
(0.662)\end{array}$ & $\begin{array}{c}-0.222^{* * *} \\
(0.053)\end{array}$ & & & & & & $\begin{array}{l}-0.066 \\
(0.119)\end{array}$ & $\begin{array}{l}-0.150^{*} \\
(0.097)\end{array}$ & $\begin{array}{c}-0.221^{* * *} \\
(0.081)\end{array}$ & $\begin{array}{c}-0.191^{* *} \\
(0.080)\end{array}$ & $\begin{array}{l}-0.204^{*} \\
(0.112)\end{array}$ \\
\hline $\begin{array}{l}\text { Tariff*Garme } \\
\text { nt }\end{array}$ & $\begin{array}{c}0.156^{* *} \\
(0.046)\end{array}$ & & & & & & & & - & - & - & - & - \\
\hline Firm Size & $\begin{array}{c}-0.205 * * * \\
(0.027)\end{array}$ & $\begin{array}{c}-0.480 * * * \\
(0.080)\end{array}$ & $\begin{array}{c}-0.180 * * * \\
(0.022)\end{array}$ & $\begin{array}{c}-0.090 * * \\
(0.043)\end{array}$ & $\begin{array}{c}-0.178 * * * \\
(0.041)\end{array}$ & $\begin{array}{c}-0.179 * * * \\
(0.035)\end{array}$ & $\begin{array}{c}-0.232 * * * \\
(0.043)\end{array}$ & $\begin{array}{c}-0.273 * * * \\
(0.053)\end{array}$ & $\begin{array}{c}-0.088^{* *} \\
(0.045)\end{array}$ & $\begin{array}{c}-0.173 * * * \\
(0.040)\end{array}$ & $\begin{array}{c}-0.180 * * * \\
(0.042)\end{array}$ & $\begin{array}{c}-0.239 * * * \\
(0.044)\end{array}$ & $\begin{array}{c}-0.266 * * * \\
(0.052)\end{array}$ \\
\hline Firm Age & $\begin{array}{c}-0.006^{* *} \\
(0.002)\end{array}$ & $\begin{array}{c}-0.346^{* * *} \\
(0.107)\end{array}$ & $\begin{array}{l}-0.004 * \\
(0.002)\end{array}$ & $\begin{array}{l}-0.005 \\
(0.004)\end{array}$ & $\begin{array}{l}-0.007 * \\
(0.004)\end{array}$ & $\begin{array}{c}-0.004 \\
(0.004)\end{array}$ & $\begin{array}{l}-0.002 \\
(0.004)\end{array}$ & $\begin{array}{c}-0.007 * \\
(0.004)\end{array}$ & $\begin{array}{l}-0.005 \\
(0.004)\end{array}$ & $\begin{array}{l}-0.006^{*} \\
(0.004)\end{array}$ & $\begin{array}{c}-0.004 \\
(0.003)\end{array}$ & $\begin{array}{l}-0.002 \\
(0.003)\end{array}$ & $\begin{array}{l}-0.007^{*} \\
(0.003)\end{array}$ \\
\hline $\begin{array}{l}\text { Foreign } \\
\text { ownership }\end{array}$ & $\begin{array}{c}0.020 \\
(0.087)\end{array}$ & - & $\begin{array}{c}0.037 \\
(0.084)\end{array}$ & $\begin{array}{c}-0.333^{*} \\
(0.200)\end{array}$ & $\begin{array}{c}-0.111 \\
(0.114)\end{array}$ & $\begin{array}{c}0.025 \\
(0.141)\end{array}$ & $\begin{array}{c}0.122 \\
(0.140)\end{array}$ & $\begin{array}{l}-0.040 \\
(0.217)\end{array}$ & $\begin{array}{c}-0.345^{*} \\
(0.211)\end{array}$ & $\begin{array}{c}-0.126 \\
(0.124)\end{array}$ & $\begin{array}{c}0.036 \\
(0.165)\end{array}$ & $\begin{array}{c}0.116 \\
(0.134)\end{array}$ & $\begin{array}{c}-0.102 \\
(0.225)\end{array}$ \\
\hline Constant & $\begin{array}{c}7.302 * * * \\
(0.173)\end{array}$ & $\begin{array}{c}16.925 * * * \\
(4.597)\end{array}$ & $\begin{array}{c}11.721^{* *} \\
(6.618)\end{array}$ & $\begin{array}{c}14.368 * * * \\
(3.439)\end{array}$ & $\begin{array}{c}22.946 * * * \\
(8.895)\end{array}$ & $\begin{array}{c}14.109^{* *} \\
(7.123)\end{array}$ & $\begin{array}{l}11.802 * \\
(8.590)\end{array}$ & $\begin{array}{l}-0.495 \\
(4.621)\end{array}$ & $\begin{array}{c}5.547 * * * \\
(0.278)\end{array}$ & $\begin{array}{c}6.390 * * * \\
(0.143)\end{array}$ & $\begin{array}{c}6.854 * * * * \\
(0.132)\end{array}$ & $\begin{array}{c}7.404 * * * \\
(0.184)\end{array}$ & $\begin{array}{c}8.206 * * * \\
(0.259)\end{array}$ \\
\hline R-squared & 0.212 & 0.037 & 0.158 & 0.131 & 0.127 & 0.126 & 0.132 & 0.159 & 0.130 & 0.127 & 0.126 & 0.133 & 0.159 \\
\hline Observations & 856 & 856 & 856 & 856 & 856 & 856 & 856 & 856 & 856 & 856 & 856 & 856 & 856 \\
\hline Ind. Dummies & No & No & No & Yes & Yes & Yes & Yes & Yes & No & No & No & No & No \\
\hline
\end{tabular}

